\title{
Amphibian Pathogen Batrachochytrium dendrobatidis Is Inhibited by the Cutaneous Bacteria of Amphibian Species
}

\author{
Reid N. Harris, ${ }^{1}$ Timothy Y. James, ${ }^{2}$ Antje Lauer, ${ }^{1}$ Mary Alice Simon, ${ }^{1}$ and Amit Patel ${ }^{2}$ \\ ${ }^{1}$ Department of Biology, MSC 7801, James Madison University, Harrisonburg, VA 22807 \\ ${ }^{2}$ Department of Biology, Duke University, Box 90338, Durham, NC 27708
}

\begin{abstract}
Population declines of amphibian species in many parts of the world are associated with a lethal fungal pathogen, Batrachochytrium dendrobatidis. Using laboratory challenge assays, we describe the inhibition of $B$. dendrobatidis by members of eight genera of bacteria isolated from the skin of two amphibian species that exhibit parental care behavior (Plethodon cinereus and Hemidactylium scutatum). We found that members of three genera of bacteria isolated from the skins of the salamander $P$. cinereus and members of seven genera isolated from the salamander $H$. scutatum inhibited the growth of $B$. dendrobatidis. Understanding how $B$. dendrobatidis interacts with an ecological community of cutaneous flora may be important in explaining and preventing amphibian population declines.
\end{abstract}

Key words: Amphibia, bacteria, Batrachochytrium, Chytridiomycota, fungi, pathogen

\section{INTRODUCTION}

The fungal pathogen Batrachochytrium dendrobatidis causes amphibian mortality and is associated with population declines and extinctions in various locations in the world, such as Central America, western areas of the United States, and Australia (Berger et al., 1998; Daszak et al., 1999; Carey et al., 2003; Lips et al., 2005). This Chytridiomycete fungus grows on amphibian skin, where it is associated with keratinized tissues (Carey et al., 2003). The fungus can be inhibited by antimicrobial peptides secreted by some frog and salamander species (Rollins-Smith et al., 2005). Among species exposed to $B$. dendrobatidis, some populations have declined while others have not declined or have recovered after a decline (McDonald and Alford, 1999; Retallick et al.,

Published online: January 21, 2006

Correspondence to: Reid N. Harris, e-mail: harrisrn@jmu.edu
2004; Lips et al., 2005). There are several possibilities for this pattern, including variation in the pathogenicity of B. dendrobatidis, variation in the effectiveness of amphibians' antimicrobial peptide secretions, and population-level variation in skin shedding rate, life history, and behavior. Another possibility is population-level variation in the amphibians' cutaneous microflora.

Species of bacteria that live on the epidermis of amphibians produce antibiotics that are effective against pathogenic fungi (Austin, 2000). Many species of frogs and salamanders lay eggs in terrestrial nests, which are brooded (attended by parents). The antifungal flora of brooders can inhibit fungi that are pathogens of embryos (Austin, 2000). We hypothesize that species that brood their embryos may be less affected by postembryonic pathogens, such as B. dendrobatidis, than species that do not attend their embryos. Observational evidence that supports this hypothesis is that of the known species of terrestrial- 
breeding, direct-developing Australian microhylid frogs, none is known to have declined (McDonald and Alford, 1999). All of these microhylid species for which reproductive behavior is known brood their eggs. Almost all of these microhylid species are sympatric with nonbrooding anuran species that have had severe population declines in association with $B$. dendrobatidis (McDonald and Alford, 1999). In this report, we document that members of eight genera of the cutaneous bacterial flora of the salamanders Plethodon cinereus and Hemidactylium scutatum strongly inhibit $B$. dendrobatidis in laboratory challenge assays.

\section{Methods}

A sample of 28 individuals of $P$. cinereus was collected in October 2004 in Rockingham County, Virginia. This species is entirely terrestrial, and females brood their embryos in nests. A population sample of 88 individuals of H. scutatum was collected during April and May 2005 in Rockingham County, Virginia. This species has a complex life cycle, with aquatic larvae and terrestrial juveniles and adults. Females brood their embryos in terrestrial pond-side nests. All individuals were rinsed twice in sterile dechlorinated tap water to remove transient cutaneous flora. Individuals were swabbed on their left, right, and ventral surfaces with a sterile cotton swab, which was then streaked onto plates containing Difco R2A (Becton, Dickinson and Co., Sparks, MD) medium (e.g., Matos et al., 2005). Several hundred bacterial isolates were obtained from both salamander species. These were challenged against Mariannaea sp., which is an ascomycete fungus that is pathogenic to salamander eggs (unpublished data). Isolates that showed strong inhibition to Mariannaea sp. in challenge assays were identified by sequence analysis of 1,400 bases of the 16S rRNA gene. Identifications were based on sequence similarity to GenBank sequence database entries (http://www. ncbi.nlm.nih.gov). These bacterial isolates were subsequently challenged against $B$. dendrobatidis. Challenge assays were conducted by growing $B$. dendrobatidis (strains JEL197 and JEL 310, University of Maine, Orono, $\mathrm{ME)}$ on $1 \%$ tryptone plates containing $1 \%$ agar and waiting until maximum zoospore production was observed. No differences between strains of $B$. dendrobatidis were observed in the challenge assays presented below. Approximately $3 \mathrm{ml}$ of distilled water was added to the plates, which were tilted in order to pipette off the water and zoospores. These zoospores were then added to fresh $1 \%$ tryptone plates and spread across their entire surface. The plates were dried in a laminar flow hood. Bacteria from freshly growing cultures were streaked across the plates in one line, and bacteria from a freshly growing culture that was known not to inhibit $B$. dendrobatidis were streaked across the same plate in another parallel line as a negative control. The plates were incubated inverted at room temperature $\left(23^{\circ} \mathrm{C}\right)$. Bacterial isolates were scored as either not inhibitory if no zone of inhibition developed or inhibitory if a clear zone of inhibition developed between the bacterial streak and the $B$. dendrobatidis culture. These zones were often large $(>1 \mathrm{~cm})$. Additional control plates contained a lawn of zoospores of $B$. dendrobatidis and only one bacterial streak from a species known not to inhibit B. dendrobatidis.

Isolates of Mariannaea sp. were tested against bacterial isolates by streaking the bacteria on R2A medium in the bottom third of a plate, waiting 1 day, and introducing a square centimeter of fungi in the top third of the plate. Some additional challenge assays were conducted between bacterial isolates and Basidiobolus ranarum (strain NRRL34594; United States Department of Agriculture Agricultural Research Service, Peoria, IL) and Allomyces sp. (strain 47-04; U.C. Berkeley Microgarden, Berkeley, CA) to test for the generality of inhibition. These assays were conducted in the same way as those conducted for Mariannaea sp. Bacterial isolates were scored as inhibitory if a zone of inhibition was maintained. All inhibitory bacterial isolates were stored in tryptic soy broth with glycerin at $80^{\circ} \mathrm{C}$ for future use and for sharing with other members of the scientific community.

\section{Results}

Control plates showed a complete lawn of $B$. dendrobatidis across the plate (Fig. 1). We isolated members of seven genera of bacteria from the skin of $H$. scutatum (Table 1) and members of three genera of bacteria from the skin of $P$. cinereus that showed strong inhibition of $B$. dendrobatidis (Table 1, Fig. 2). For both species of amphibians, the majority of genera were isolated from multiple individuals. For Arthrobacter, Pedobacter, and Pseudomonas, several species of each genus were isolated that inhibited $B$. dendrobatidis. The bacteria that did not inhibit $B$. dendrobatidis exhibited the same variation in pattern of confluent growth as did the bacteria that did inhibit $B$. dendrobatidis. This 


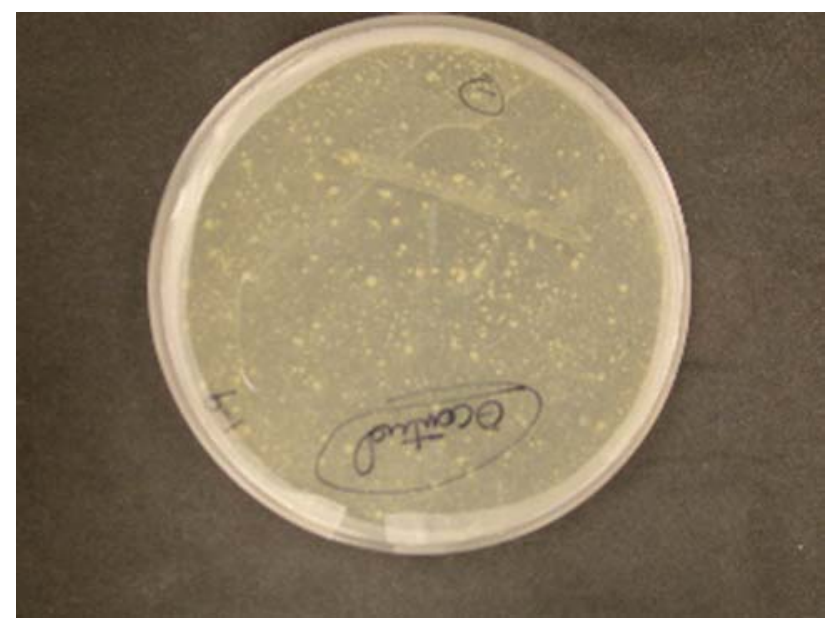

Figure 1. Control plate with a dense lawn of $B$. dendrobatidis zoospores and zoosporangia and a streak of a bacterial isolate that did not inhibit B. dendrobatidis.

Table 1. Bacterial Isolates Belonging to These Genera Were Sampled from the Skins of Salamanders H. scutatum and P. cinereus: Members of These Genera Inhibited B. dendrobatidis in Challenge Assays

\begin{tabular}{ll}
\hline Amphibian species & $\begin{array}{l}\text { Isolates of genera that } \\
\text { inhibited B. dendrobatidis }\end{array}$ \\
\hline H. scutatum & Arthrobacter \\
& Bacillus \\
& Kitasatospora \\
& Paenibacillus \\
& Pedobacter \\
& Pseudomonas \\
Streptomyces & Bacillus \\
Lysobacter \\
Pseudomonas
\end{tabular}

pattern suggests that general nutrient depletion is not an adequate explanation for the observed zones of inhibition in the performed challenge assays and supports the explanation that inhibitory compounds are produced by bacterial isolates. Examination of the plates under the microscope revealed swimming zoospores of $B$. dendrobatidis near the control streak of bacteria and no evidence of living $B$. dendrobatidis near the streaks of inhibitory bacteria. All tested antichytrid bacterial species also demonstrated broad antifungal abilities by inhibiting the growth of Mariannaea sp., and members of the genera

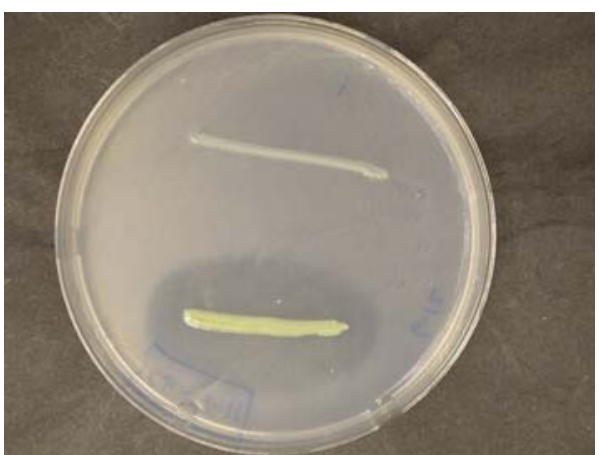

Figure 2. Lysobacter gummosus strain Rb27-11 from the skiin of the salamander $P$. cinereus did inhibit $B$. dendrobatidis.

Bacillus, Lysobacter, and Pedobacter also inhibited the growth of Basidiobolus ranarum and Allomyces sp.

\section{DIsCUSSION}

Our results demonstrate that diverse bacterial species inhabiting the skins of two species of salamanders inhibit the growth of fungi, including the pathogen $B$. dendrobatidis in vitro. There is no reason to believe that similar effects do not occur in vivo and that antimicrobial skin flora are likely to have a major role in determining the susceptibility of amphibians to chytridiomycosis. An important determinant of the outcome of infection is likely to be the density of inhibitory bacteria and the density of pathogen fungi to which the amphibian is exposed.

Amphibian population declines in various parts of the world are associated with $B$. dendrobatidis and are ongoing (Ron and Merino, 2000; Bosch et al., 2001; Hanselmann et al., 2004). Surveys and experiments are urgently needed to test the efficacy of a diversity of amphibian species' cutaneous flora in preventing chytridiomycosis. Experimentally, individuals with and without cultured antichytrid flora can be exposed to $B$. dendrobatidis and the pathogenicity of chytridiomycosis can be assayed. Populations that have declined due to $B$. dendrobatidis and then recovered can be surveyed with the prediction that survivors will have more potent antimicrobial peptides (Rollins-Smith et al., 2005), an antichytrid cutaneous flora, or both. Species that brood their embryos, such as $P$. cinereus, H. scutatum, and many frog species, may be more likely to harbor antifungal bacteria because they have been selected to apply their antifungal skin flora to their embryos. Such parent-to-offspring vertical trans- 
mission could explain the observed pattern that terrestrial species that brood their embryos are less likely to show fungus-related population declines than pond- and stream-dwelling species (McDonald and Alford, 1999), although other explanations are possible (Lips et al., 2003). In initial studies with a pond-breeding frog that does not brood its eggs, Rana muscosa, we have isolated bacteria that inhibit $B$. dendrobatidis, which suggests that nest attendance behavior is not a requirement for an antifungal cutaneous flora. Antifungal cutaneous bacteria may be widespread among amphibian species. The anti- $B$. dendrobatidis compounds produced by these bacteria have yet to be characterized and are the focus of ongoing research. The ecological interactions between bacteria and $B$. dendrobatidis on amphibian skin are likely to be complex and important in understanding amphibians' susceptibility to this fungal pathogen.

Current ideas on ameliorating the effects of $B$. dendrobatidis on amphibian populations include practices that limit movement of the fungus among areas, such as quarantine (Australian Government, 2004). While such practices are important, it appears that this fungal species is already geographically widespread in many areas of the world and that containment will be difficult to achieve (Speare and Berger, 2000). An exciting aspect of a cutaneous antichytrid flora is that it could be harvested from resistant individuals and inoculated onto susceptible individuals. In addition, amphibians would likely transmit the beneficial skin flora among themselves during activities such as mating, aggressive interactions, and congregating in hibernacula. A flora that inhibits $B$. dendrobatidis may help amphibian individuals already affected by stressors such as pesticides, drier conditions, and high population density, to avoid the lethal effects of chytridiomycosis.

\section{ACKNOWLEDGMENTS}

The authors thank Emily André, Jeni Banning, Karen Duncan, William Flint, and Trey Wahl for assistance in the laboratory and field and Ivor Knight and Grace Wyngaard for helpful and stimulating discussions. We thank Joyce Longcore for providing us with isolates of $B$. dendrobatidis. This work was supported by the National Science Foundation (grant 0413981) and the Thomas F. Jeffress and Kate Miller Jeffress Memorial Trust.

\section{REFERENCES}

Austin RM (2000) Cutaneous microbial flora and antibiosis in Plethodon ventralis. In: The Biology of Plethodontid Salamanders, Bruce RC, Jaeger RG, Houck LD (editors), New York: Kluwer Academic/Plenum, pp 127-136

Australian Government, Department of Environment and Heritage (2004) Draft threat abatement plan for infection of amphibians with chytrid fungus resulting in chytridiomycosis. Available: http://www.jcu.edu.au/school/phtm/PHTM/frogs/ TAP/amphibians.pdf. [accessed September 22, 2005]

Berger L, Speare R, Daszak P, Green DE, Cunningham AA, Goggin CL, et al. (1998) Chytridiomycosis causes amphibian mortality associated with population declines in the rain forests of Australia and Central America. Proceedings of the National Academy of Sciences USA 95:9031-9036

Bosch J, Martínez-Solano I, García-París M (2001) Evidence of a chytrid fungus infection involved in the decline of the common midwife toad (Alytes obstetricans) in protected areas of central Spain. Biological Conservation 97:331-337

Carey C, Pessier AP, Peace AD (2003) Pathogens, infectious disease, and immune defenses. In: Amphibian Conservation, Semlitsch R (editor), Washington DC: Smithsonian Institution Press, pp 127-136

Daszak P, Berger L, Cunningham AA, Hyatt AD, Green DE, Speare R (1999) Emerging infectious diseases and amphibian population declines. Emerging Infectious Diseases 5:735748

Hanselmann R, Rodriguez A, Lampo M, Fajardo-Ramos L, Aguirre AA, Kilpatrick AM, et al. (2004) Presence of an emerging pathogen of amphibians in introduced bullfrogs (Rana catesbeiana) in Venezuela. Biological Conservation 120: 115-119

Lips KR, Burrowes PA, Mendelson JR, Parra-Olea G (2005) Amphibian declines in Latin America: widespread population declines, extinctions, and impacts. Biotropica 37:163165

Lips KR, Reeve JD, Witters LR (2003) Ecological traits predicting amphibian population declines in Central America. Conservation Biology 17:1078-1088

Matos A, Kerkhof L, Garland JL (2005) Effects of microbial community diversity on the survival of Pseudomonas aeruginosa in the wheat rhizosphere. Microbial Ecology 49:257264

McDonald KR, Alford RA (1999) A review of declining frogs in northern Queensland. In: Declines and Disappearances of Australian Frogs, Campbell A (editor), Canberra: Environment Australia, pp 14-22

Retallick RW, McCallum RH, Speare R (2004) Endemic infection of the amphibian chytrid fungus in a frog community postdecline. PLoS Biology 2:e351

Rollins-Smith LA, Reinert LK, O'Leary CJ, Houston LE, Woodhams DC (2005) Antimicrobial peptide defenses in amphibian skin. Integrative and Comparative Biology 45:137-142

Ron SR, Merino A (2000) Amphibian declines in Ecuador: overview and first report of chytridiomycosis from South America. FrogLog 42:2-3

Speare R, Berger L (2000) Global distribution of chytridiomycosis in amphibians. Available: http://www.jcu.edu.au/school/phtm/ PHTM/frogs/chyglob.htm [accessed September 22, 2005] 